\section{Comparison of Proton Magnetic Resonance Spectra of Cell-wall Mannans of Candida tropicalis} with Its Morphology

\section{Takashi HiRATA and Takasuke IsHITANI}

\author{
National Food Research Institute, \\ Ministry of Agriculture and \\ Forestry, Tokyo, Japan
}

Received February 2, 1976

Some, but not all fungi are known to exhibit dimorphism. Various physical and chemical factors $^{1)}$ such as temperature of cultivation, light, carbon and nitrogen sources in the culture medium have been shown to affect the development of dimorphism. In addition, since morphological differences might be due to the chemical composition of the cell-wall of each form, many investigations have been undertaken to determine the quantitative differences in the cell-wall materials. ${ }^{2 \sim 5)}$ However, the structural changes of cell-wall mannans, which might be responsible for the morphological changes of true fungi, are little known.

Using Proton Magnetic Resonance spectroscopy, which is a powerful method in the elucidation of structural problems involving complex polymers such as yeast mannans, ${ }^{\text {; }}$ a comparative study was made on the cell-wall mannans extracted from Candida tropicalis, which exhibits dimorphism depending upon carbon sources in the culture medium. ${ }^{7}$

The yeast used in this study was Candida tropicalis which can readily assimilate $n$ alkane. The yeast was grown on a basal medium containing $\left(\mathrm{NH}_{4}\right)_{2} \mathrm{SO}_{4} 4.00 \mathrm{~g},\left(\mathrm{NH}_{4}\right)_{3}$ $\mathrm{HPO}_{4} 1.28 \mathrm{~g}, \mathrm{KCl} 0.29 \mathrm{~g}, \mathrm{MgSO}_{4} \cdot 7 \mathrm{H}_{2} \mathrm{O} 0.15 \mathrm{~g}$, $\mathrm{CaCl}_{4} \cdot 2 \mathrm{H}_{2} \mathrm{O} \quad 0.19 \mathrm{~g}, \quad \mathrm{CuSO}_{4} \cdot 5 \mathrm{H}_{2} \mathrm{O} 0.78 \mathrm{mg}$, $\mathrm{FeCl}_{3} \cdot 6 \mathrm{H}_{2} \mathrm{O} 8.00 \mathrm{mg}, \mathrm{ZnSO}_{4} 3.00 \mathrm{mg}, \mathrm{MnSO}_{4} \cdot$ $n \mathrm{H}_{2} \mathrm{O} 3.5 \mathrm{mg}$, corn steep liquor $1 \mathrm{~g}$, glucose $10 \mathrm{~g}$ or $n$-pentadecane $10 \mathrm{~g}$, and water $1000 \mathrm{ml}$, which was adjusted to $\mathrm{pH}$ 5.2. The cells, precultured on malt extract broth at $30^{\circ} \mathrm{C}$ overnight, were inoculated in the medium which was dispensed in a volume of $100 \mathrm{ml}$ of $500 \mathrm{ml}$ flasks. The flasks, then, were incubated on a reciprocal shaker at $30^{\circ} \mathrm{C}$. Cells on the stationery phase were harvested by centrifugation and washed twice with distilled water. Acetone powder was prepared from the washed cells. The isolation and purification of mannans from the cells were carried out as previously reported by Gorin and Spencer. ${ }^{8}$ The PMR spectra of mannans were obtained using a JES-PS 100 spectrometer equipped with a temperature control unit, from $0.4 \mathrm{ml} \mathrm{D}{ }_{2} \mathrm{O}$ solution containing $80 \mathrm{mg}$ mannan at $70^{\circ} \mathrm{C}$ with 3-(trimethylsilyl) propane sulfonic acid $\mathrm{Na}$ salt as an internal standard.

When Candida tropicalis was grown on a medium containing glucose as the sole carbon source, the cells developed into the so-called yeast-like form which showed such a C-1 proton PMR spectrum of the cell-wall mannan as shown in Fig. 1 (A). The spectrum is characterized by three strong peaks at $\delta: 4.89,5.02$, 5.19 and two small peaks. On the other hand, addition of $0.05 \%$ triton $\mathrm{X}$ to the medium containing $n$-pentadecane resulted in the devel-

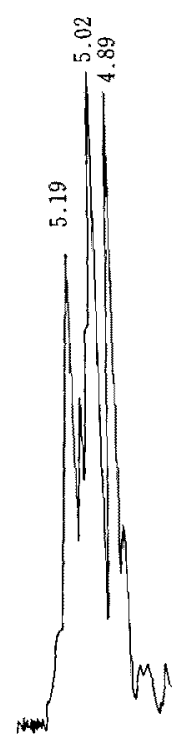

(A)

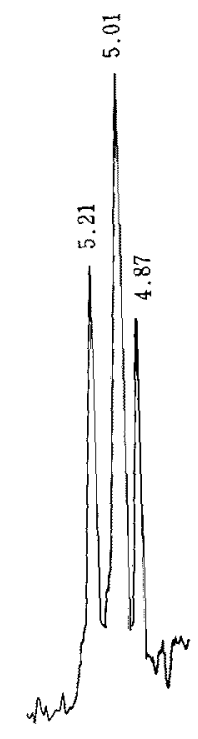

(B)
FIG. 1. H-1 Portion of Proton Magnetic Resonance Spectra of Cell-wall Mannans Prepared from Yeastlike Cells (A) and Filamentous Cells (B) (chemical shifts in $\delta$ ). 
opment of filamentous cells. The PMR spectrum of the filamentous cells is given in Fig. 1 (B). Three strong peaks at $\delta: 4.87,5.01$, 5.21 were observed for the spectrum but the minor peaks were not detected at all. Moreover, the relative intensities of the peaks given in Fig. I (B) are different from those in Fig. I (A). Yeast-like cells were also obtained from the glucose medium containing $0.05 \%$ triton $\mathrm{X}$ or the $n$-pentadecane medium free from the detergent. In such cases PMR spectrum patterns were of intermediary type between Figs. 1 (A) and (B). The basis for the changes in the spectra depending upon the changes in the mannan structure is not precisely defined but the minor peaks detected in Fig. 1 (A) might be due to the fact that the mannans of the filamentous cells have a higher proportion of main-chain units than that of the yeastlike cells. These results indicate that the differences in the mannan structure of the cellwall are at least partly responsible for the morphological differences of the organism.

Attemps to clarify the definite mannan structure of the yeast associated with the morphological changes are now in progress and details will be presented elsewhere.

The authors thank Dr. Y. Fukazawa, Meiji Pharmaceutical College, Tokyo, Japan, for his useful suggestions.

\section{REFERENCES}

1) H. Yamaguchi and K. Iwata, Protein, Nucleic Acid, Enzyme, 17, 588 (1972).

2) S. Bartnicki-Garcia and W. J. Nickerson, Biochim. Biophys. Acta, 58, 102 (1962).

3) F. W. Chattaway, M. R. Holmes and A. J.E. Barlow, J. Gen. Microbiol., 51, 367 (1968).

4) F. Kanematsu, L. M. Carbonell, R. E. Moreno and J. Rodriguez, J. Bact, 97. 1036 (1969).

5) F. Kanematsu and L. M. Carbonell, ibid., 106, 946 (1971).

6) P. A. J. Gorin and J. F. T. Spencer, Advan. Appl. Microbiol., 13, 25 (1970).

7) M. Hirai, S. Shimizu, Y. Teranishi, A. Tanaka and S. Fukui, Agr. Biol. Chem., 36, 2335 (1972).

8) P. A. J. Gorin and J. F. T. Spencer, Can. J. Chem., 46, 2299 (1968). 